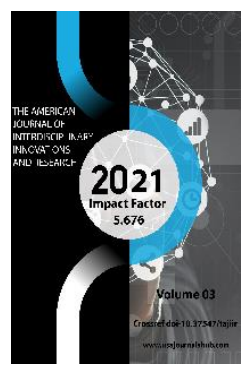

\title{
The Art Of Khorezmian Sculpture: Appearance And Specificity
}

\author{
Abdullayev M.S. \\ PhD, Teacher Of The Department Of History, Urgench State University, Uzbekistan \\ Matniyozov S.S. \\ MA Student In History, Urgench State University, Uzbekistan
}

Copyright: Original content from this work may be used under the terms of the creative commons attributes 4.0 licence.

\section{ABSTRACT}

This article is devoted to the formation and development of Khorezmian sculpture art, which describes the emergence, artistic features, historical significance, as well as the peculiarities of Khorezm sculpture art.

\section{KEYWORDS}

Khorezm, art, sculpture, mahogany, terracotta, ceramics, bone, stone, Tuprakkala, Qal'liqir-2, Koyqirilgan kala

\section{INTRODUCTION}

"When we say Khorezm, we mean a unique country that has made a worthy contribution to the development of world science, culture 
and art, laid the foundation of the Uzbek statehood." 1

It is well-known that fine arts are one of the types of art that quickly affect the human mind, evoke good feelings and enrich the spiritual world. At the same time, the fine arts are also educators that help the formation and maturation of the human personality. In their works, the artists express a certain view of events and happenings, different situations, reveals the inner essence through the image, depicts the spiritual image, psychological (mental) state and thoughts of people.

Fine art emerged in very ancient times, as a result of the development of the labor process. In the process of labor, human thinking has matured, the sense of beauty has increased, and the concepts of beauty, convenience, and usefulness in reality have expanded.

By ancient Khorezmian art we mean the art of the period from the appearance of buds of art in the Khorezm oasis to Islam, to be clear from

\footnotetext{
${ }^{1}$ Mirziyoyev Sh.M. Buyuk kelajagimizni mard vaa olijanob xalqimiz bilan birga quramiz. Tashkent: Uzbekistan, 2017. 241-b.

${ }^{2}$ Pugachenkova G. A., Rempel L. I. Istoriya iskusstv Uzbekistana s drevneyshix vremen do seredini devyatnadtsatogo veka. - M.: Iskusstvo, 1965. - 688 s.; Pugachenkova G. A., Rempel L. I. Ocherki iskusstvo Sredney Azii: drevnost i srednevekove. M.: Iskusstvo, 1982. - $288 \mathrm{~s}$.

${ }^{3}$ Xakimov A. Iskusstvo Uzbekistana: istoriya i sovremennost. - Tashkent: San'at, 2010. - 502 s.; Xakimov A.A. Xorezm v itorii gosudarvennosti Uzbekistana / Osobennosti razvitiya kulturы Xorezma s drevnosti do VIII veka. - T., 2013. - S. 272-284.
}

the beginning of the VIII century. There is a lot of information about the art of Khorezm in ancient times and although archeologists and historians have turned to this field, however Khorezmian art has not been studied yet from the point of view of art criticism.

Pre-Islamic Khorezmian art is partially covered in the works of art critics such as G.A Pugachenkova, L.I Rempel ${ }^{2}$, A.A Hakimov³, D.A Fakhretdinova 4 . The researches of famous archeologists, historians and orientalists provide valuable information about the culture and art of ancient Khorezm. In particular, there are important materials in the materials of the Khorezm Archaeological and Ethnographic Expedition (XAEE) led by SP Tolstov ${ }^{5}$, in the works of Ya. Gulomov' ${ }^{6}$, Yu.A. Rapoport 7 , M.G. Vorobeva $^{8}$, B.I.Vaynberg ${ }^{9}$, M.Mambetullaev ${ }^{10}$, V.Yagodin. ${ }^{11}$

Most of the research was done in the middle and second half of the twentieth century. Further research includes academician AA Hakimov's "Art of Uzbekistan: history and modernity" and "Khorezm in the history of

\footnotetext{
${ }^{4}$ Faxreddinova D. Dekorativno-prikladnoe iskusstvo Uzbekistana. - Tashkent: O'zbekiston, 2000. - 280 s.

5 TXAEE. I-XVI t. - M., 1952-1991.

${ }^{6}$ Gulomov Ya.G. History of irrigation in Khorezm. T .: Fan, 1959.

${ }^{7}$ Rapoport Yu.A. Koy-Kirilgan-kala kak pamyatnik pogrebalnogo kulta // Koy-Kirilgan-kala - pamyatnik kultura drenogo Xorezma. IV v. d.n. - IV v.n.e. - M., 1967. S.227-251.

${ }^{8}$ Vorobeva M.G. Xorezmskie terrakoti // Kultura i iskusstvo drevnogo Xorezma. - M.: Nauka, 1981. S. 184-194.

${ }^{9}$ Vaynberg B.I. Moneti drevnego Xorezma. - M.:

Nauka, 1977. - 194 s.

${ }^{10}$ Mambetullaev M. Pottery statues of Khorezm // Art. - T., 2000. - №3. - B.4-6.

${ }^{11}$ Yagodin V., Betss A. Pictures of unknown rulers of Khorezm // Science and life. - T., 2008. 3-4-5. - 110117.
} 
statehood of Uzbekistan", "Features of the development of culture of Khorezm from antiquity to the VIII century" and a number of other articles, M. Mambetullaev's scientific articles, A.Betss, G.Khodjaniyazov's scientific works on Oqchahon fortress can be cited.

Due to the lack of large mountains in the Khorezm oasis, the most ancient rock carvings and petroglyphs are almost non-existent. Khorezm has long been one of the regions where sculpture was developed. The first sculptures in Khorezm were found at the site of Joytun and date back to the Neolithic period and are associated with the matriarchal system. The influence of early religious beliefs on the formation and development of sculpture was also strong here.

Kaltaminor culture periodized by the V-IV millennia. BC. It is known that the Kaltaminors lived mainly on hunting and fishing,. Remains of many stone and pottery objects have been found in the Tozabogyop culture of the 3 rd-2nd millennia BC. Representatives of the Suvyorgan and Amirabad cultures were actively involved in agriculture. Stone and bone statues of female goddesses have been found in these Neolithic and Bronze Age monuments.

The monuments of Kozalikir and Dingilja of the Archaic period (VII-VI centuries) have been studied. The elements of the city are clearly visible in the mirror. In the VI-IV centuries BC, Khorezm was subordinated to the Achaemenids of Iran and had active economic and cultural relations with the countries of the East. The development of Khorezmian art in antiquity dates back to antiquity (IV-IV centuries BC). Hundreds of archeological monuments of this period have been studied and many different works of art have been found in them.

The monumental and terracotta-small sculptures of Khorezm sculpture were included in the study. In Khorezm, the statues are mainly made of ceramics and plaster, a common material in the region. In ancient Khorezm, statues of copper, bronze and gold - cast, terracotta ceramics, plaster and stone - were also found. Pottery masks, embossed objects, ostads and coins are also common.

The literature on the archeological monuments discovered during the research of the Khorezm archeological and ethnographic expedition is given in the literature. Small sculptures made of ceramic plaster were found in the monuments of Jonbosqala, Bozorqala, Teshikkala, Koyqirilganqala, Qalaliqir, monumental statues and murals were found in the monuments of Qoyqirilganqala, Qalaliqir, Elkharas.

Small sculptures often feature images of gods, women, as well as men, various animals, and mythical creatures. There are various scenes in the murals and human figures on the walls. Plastic, painting and embossing techniques were used to process the images.

The monumental sculpture found during the excavations in 1947 entered a completely new page in the ancient art of Khorezm. It is rich in sculptural materials. Nine rooms have been excavated of unburned clay sculptures. The total number of these statues whose fragments have survived is more than 30 , two of which are almost whole (no head), plus four heads (one has a long hat), two hats, five without heads, the whole body without limbs, the base of about 15 statues without moving 
from the place where the legs were placed, the lower part of the two statues in a sitting position, and the number of bodies, arms, legs, clothing, and the like there were countless fragments. Among the fragments should be noted a large fragment of the image of a rider (original size) relief, a horse with a very ornate bridle and the folds of the rider's cloak. ${ }^{12}$

Qoyqirilganqala was built in III-IV centuries BC. It is located $22 \mathrm{~km}$ from the city of Turtkul in Karakalpakstan. It had separate rooms for kings and soldiers, and halls of victory. The temple building has two floors and a diameter of $44.4 \mathrm{~m}$. Its height is $9.5 \mathrm{~m}$. Inside the building, there are 8 domed rooms with murals, as well as masterfully crafted ceramic coffins, statues, and murals. ${ }^{13}$

Clay sculptures and bas-reliefs were found in the palaces of Khorezm rulers in Tuprakkala (IIIV centuries). On the walls, various objects are depicted in high reliefs. Images of the rulers and their families are displayed in the form of huge statues placed on special shelves. The sculptures reflect the traditions of Hellenistic art in plastic modeling and composition. However, Khorezm sculptors showed originality in their interpretation. ${ }^{14}$

The oldest figurines are flat and conditional. The peculiarity of these statues is that they pay great attention to the details of the costumes.

Terracotta statues date back to ancient Khorezm. It appeared in the IV century BC. This was the time when Khorezm left the Achaemenid Empire and gained state

12 Tolstov S.P. In search of ancient Khorezm culture. - T .: Fan, 1964. - 220-p.

${ }^{13}$ Koy-Kirilgan-kala - pamyatnik kultura drenogo Xorezma. IV v. d.n. - IV v.n.e. - M., 1967. - S.230. independence. Perhaps, during this period there were some changes in the field of ideology, as a result of which the same type of miniature anthropomorphic and zoomorphic images of the ancient Khorezmian gods appeared and became widespread.

Among anthropomorphs, female statues predominate. Most of them were made of clay and left a mark in the form of a special mold. From the 3 rd century $B C$, plaster figurines appeared in everyday life. From the end of the 4th century $A D$, the tradition of mass production of miniature images of the gods was almost completed.

Ancient sculpture was associated with religious beliefs, and mostly statues of female goddesses were found. Anaxita, the goddess of water and fertility, has a special place in this. Subsequent archeological excavations have also uncovered Anaxita statues in Katkala and Khumbuztepa.

Other types of terracotta depicting women, such as the "mirror goddess," are known. At the end of antiquity, new species of terracotta appeared. Among them are statuettes depicting a woman sitting with her legs crossed, wearing a long dress and bare head. These statues partially oust the image of the "scarf goddess" from everyday life. ${ }^{15}$

The images of people are embossed on the statues as well as on the dishes. The eagle must have been depicted as wearing a long helmet similar to that of a rider and an Attic who held a long spear in his bed (this helmet is similar to

\footnotetext{
14 Tolstov S.P. In search of ancient Khorezm culture. - T .: Fan, 1964. - 149-p.

${ }^{15}$ Yagodin V.N. Pamyatniki drevnego iskusstva

Karakalpakistana // http://kungrad.com
} 
the helmets worn by kings depicted on coins in the latest ( $3 r d$ century AD) coins).) the figure of an infantryman gives new details to depict the clothing heads and weapons of the ancient Khorezmians.

Among the images of animals, there are more figures and heads of horses, sometimes in a schematic way, and sometimes in a very realistic way. This is a clear proof that the worship of horses was widespread in the religion of the Massagets, and, as noted above, there are similarities between the Khorezmian Massaget and the Phrygian culture. Although in addition to the above, there are images of camels, sheep, pigs, and even rhinos and monkeys (although belonging to a later period), but the horses are so numerous that they are accompanied only by a series of lions, which are lowered into the above-mentioned vessels can be put. Of course, this is also associated with the worship of the sun.

It is possible to assume that the statues of women depict the mother goddess Ardvisura Anaxita, the patron saint of water and irrigation in general (especially, the Amudarya), and the male figures depict the goddess Sabazi-Siyavush, the companion of the great goddess. According to Narshahi, the Zoroastrians of Bukhara annually smashed the clay statues of the gods on the day of Navruz and replaced them with other statues from a special market attended by the king himself. Apparently, this ritual, which was also depicted in Khorezm (usually all statues were broken in ancient times), was important for Old Asia,

16 Tolstov S.P. In search of ancient Khorezm culture.

- T .: Fan, 1964. - 150-p. where the fertility of the earth symbolized the death and resurrection of the goddess. ${ }^{16}$

In recent years, artifacts have been found in the Akchakhon Fortress in Beruni district, Khumbuztepa and Toshkala in Hazarasp district. Scientists from the Institute of Social Sciences and Humanities (Institute of History, Archeology and Ethnology) of the Academy of Sciences of the Republic of Uzbekistan V. Yagodin and G. Khodjaniyazov conducted research in the study of the White Castle under the guidance of scientists from the University of Sydney, Australia A. Bets. As a result of these researches, it was suggested that Akchakhon fortress was the ancient capital of Khorezm. The discovery of large-scale murals also supports this idea.

Khumbuztepa is located in Hazarasp district of Khorezm region, one side of which is washed away by the waters of the Amudarya. The monument was discovered by $M$. Mambetullaev in the 1970s. In the 1990s Yu.Manilov, S.Bolelov, Sh.Matrasulov conducted research. In 2010-2019, scientists of the Khorezm Mamun Academy regularly conducted archeological research under the scientific guidance of S.R. Baratov. As a result of research, from the 8 th century $B C$ to the 5 th century $A D$, a large pottery complex was discovered here. This monument has special importance in the study of the history of pottery, as it allows to analyze the changes in the shape and technique of various pottery products over many years. Terracotta figures depicting gods, women and various animals were found on Khumbuztepa, painted on ceramic surfaces. As a result of preliminary 
research in Tashkent, S.R. Baratov identified samples of plaster ornaments. ${ }^{17}$

We have listed a few examples of ancient Khorezmian art, which in ancient times was sealed by the creative genius of the peoples living in the lower reaches of the Amu Darya and has a special place among the magnificent monuments of ancient art of Uzbekistan. These monuments give a vivid picture of the contribution of the ancestors of the people of modern Uzbekistan to the treasury of world art.

The sculptures serve to educate our youth in the spirit of patriotism and friendship, arouse the desire to learn more about our history, and increase the interest of tourists in our country.

\section{REFERENCES}

1. Faxreddinova D. Dekorativno-prikladnoe iskusstvo Uzbekistana. - Tashkent:

O'zbekiston, 2000. $-280 \mathrm{~s}$.

2. Gulomov Ya.G. History of irrigation in Khorezm. - T .: Fan, 1959.

3. Mambetullaev M. Pottery statues of Khorezm // Art. - T., 2000. - №3. - B.4-6.

4. Mirziyoyev Sh.M. Buyuk kelajagimizni mard vaa olijanob xalqimiz bilan birga quramiz. Tashkent: Uzbekistan, 2017. 241b.

5. Pugachenkova G. A., Rempel L. I. Istoriya iskusstv Uzbekistana $s$ drevneyshix vremen do seredini devyatnadtsatogo veka. - M.: Iskusstvo, 1965. - 688 s.;

\footnotetext{
${ }^{17}$ From the report of Khorezm Mamun Academy in 2013
}

6. Pugachenkova G. A., Rempel L. I. Ocherki iskusstvo Sredney Azii: drevnost i srednevekove. - M.: Iskusstvo, 1982. - 288 s.

7. Rapoport Yu.A. Koy-Kirilgan-kala kak pamyatnik pogrebalnogo kulta // KoyKirilgan-kala - pamyatnik kultura drenogo Xorezma. IV v. d.n. - IV v.n.e. - M., 1967. S.227-251.

8. Report of Khorezm Mamun Academy in 2013

9. Tolstov S.P. In search of ancient Khorezm culture. - T .: Fan, 1964. - 149-p.

10. Toprak-kala. Dvorets // TXAEE. XIV. - M.: Nauka, 1984. $307 \mathrm{s.}$

11. TXAEE. I-XVI t. - M., 1952-1991.

12. Vaynberg B.I. Moneti drevnego Xorezma. - M.: Nauka, 1977. - 194 s.

13. Vorobeva M.G. Xorezmskie terrakoti // Kultura i iskusstvo drevnogo Xorezma. M.: Nauka, 1981. - S. 184-194.

14. Xakimov A. Iskusstvo Uzbekistana: istoriya i sovremennost. - Tashkent: San'at, 2010. - 502 s.;

15. Xakimov A.A. Kultura Xorezma doislamskogo perioda // Xorezm $v$ istorii gosudarstvennosti Uzbekistana. - T., 2013.

16. Yagodin V., Betss A. Pictures of unknown rulers of Khorezm // Science and life. - T., 2008. 3-4-5. - 110-117. 
17. Yagodin V.N. Pamyatniki drevnego iskusstva Karakalpakistana // http://kungrad.com

18. Rasuljanovna, I. N., \& Rakhmonqulovich, K. N. (2020). Trade Relations Between Ancient Bacteria And China On The II-I BC. The American Journal of Social Science and Education Innovations, 2(07), 47-51. 